Louisiana State University

LSU Digital Commons

$2-2003$

Climatic Influences on Riverine Nitrate Flux: Implications for Coastal Marine Eutrophication and Hypoxia

Dubravko Justic

R. Eugene Turner

Nancy N. Rabalais

Follow this and additional works at: https://digitalcommons.Isu.edu/oceanography_coastal_pubs

Digitalrt of the Oceanography Commons

Commons

Network

Logo 


\title{
Climatic Influences on Riverine Nitrate Flux: Implications for Coastal Marine Eutrophication and Hypoxia ${ }^{1}$
}

\author{
Dubravko Justić ${ }^{2, *}$, R. Eugene Turner ${ }^{2}$, and NAncy N. Rabalais ${ }^{3}$ \\ ${ }^{2}$ Coastal Ecology Institute, and Department of Oceanography and Coastal Sciences, \\ Louisiana State University, Baton Rouge, Louisiana 70803 \\ ${ }^{3}$ Louisiana Universities Marine Consortium, 8124 Highway 56, Chauvin, Louisiana 70344
}

\begin{abstract}
The average nitrate flux of the lower Mississippi River increased 3.3-fold between 1954-1967 and 19832000. During the same time period, the average nitrate concentration increased 2.3-fold while the average discharge increased 40\%. Partitioning of the observed trend in nitrate flux among the two flux components, nitrate concentration and discharge, revealed that about $80 \%$ of the observed increase in flux could be explained by the increase in nitrate concentration. This indicates that a historical increase in the anthropogenic nutrient inputs has had a far greater impact on the lower Mississippi River nitrate flux than a change in climate. The influence of climatic factors on nitrate flux has been significant and may further increase as a result of global climate change. This argument is supported by two lines of evidence. The residual component of nitrate flux, obtained by removing a trend from the time series, is controlled primarily by the variability in discharge, i.e., climatic factors. Also, there is a highly significant relationship between discharge and nitrate concentration at the low end of the discharge spectrum $\left(<13,000 \mathrm{~m}^{3} \mathrm{~s}^{-1}\right)$. The differences in nitrate flux between flood and drought years are significantly larger than the variations in discharge. This makes the Mississippi River nitrate flux potentially sensitive to future changes in the frequency of extreme climatic events. Because of the importance of nitrate for the productivity of coastal phytoplankton, future climate change would likely have important implications for coastal marine eutrophication and hypoxia.
\end{abstract}

\section{Introduction}

Eutrophication has been a growing problem in many coastal and estuarine ecosystems around the world (Rosenberg 1985; Diaz and Rosenberg 1995; Rabalais et al. 1999; Rabalais and Turner 2001). Typical manifestations of eutrophication include enhanced primary productivity, noxious phytoplankton blooms, and bottom water hypoxia (Officer et al. 1984; Smayda 1990; Turner and Rabalais 1994). The extent and severity of these phenomena have increased during the last 50 years (Benović et al. 1987; Justić et al. 1987; Andersson and Rydberg 1988; Cooper and Brush 1991; Hickel et al. 1993; Rabalais et al. 1996), most likely in response to increased riverine concentrations of nitrogen and phosphorus and more balanced stoichiometric nutrient ratios in freshwaters (Turner and Rabalais 1991; Dortch and Whitledge 1992; Justić et al. 1995a,b; Howarth et al. 1996). The concentrations of total phosphorus and dissolved inorganic nitrogen in the Mississippi River have increased

\footnotetext{
${ }^{1}$ Presented within two symposia dealing with essential fisheries habitat and implications of global climatic change at the American Fisheries Society's 24th Annual Larval Fish Conference at Gulf Shores, Alabama, November 6-10, 2000. Symposium and meeting conveners were Richard F. Shaw and James H. Cowan, Jr.

* Corresponding author; tele: 225/578-6394; fax: 225/5786326; e-mail: djusti1@1su.edu.
}

two-fold and three-fold, respectively, during the last 50 years, and the silicon to nitrogen ratio has decreased four-fold (Turner and Rabalais 1991). These changes in the Mississippi River nutrient concentrations and ratios have occurred coincidentally with changes in agricultural practices and increasing population density in the watershed (Turner and Rabalais 1991; Howarth et al. 1996; Goolsby et al. 1999). Historically, the global nitrogen cycle has been altered by the widespread use of fertilizer and nitrogen-fixing crops to the point where the terrestrial nitrogen budget has doubled and continues to increase (Vitousek et al. 1997). A large fraction of the excess nitrogen stored in agricultural and urban watersheds is exported as the highly mobile nitrate ion (Goolsby et al. 1999). Consequently, nitrate fluxes of the world's major rivers are strongly affected by landuse patterns and population density in watersheds (Peierls et al. 1991; Howarth et al. 1996; Caraco and Cole 1999).

Little is known about the linkages between climate variability, riverine nutrient fluxes, and coastal marine eutrophication. It was observed that short-term climate anomalies, such as droughts and floods, may substantially alter nutrient delivery to the coastal ocean and influence the eutrophication process over an annual cycle (Justić et al. 1996, 1997; Rabalais et al. 1998). Quantifying the linkage between climate variability and riverine nu- 
trient fluxes is important, particularly in the context of assessing the potential implications of future climate change for river-dominated coastal ecosystems. The global Earth's temperatures increased by almost $1^{\circ} \mathrm{C}$ during the last 150 years (Jones et al. 1999), and general circulation models (GCMs) have projected further temperature increases of $1-6^{\circ} \mathrm{C}$ over the next 100 years (IPCC 2001). An increase in global temperatures of such a magnitude would likely produce an enhanced hydrologic cycle that would be manifested in altered global freshwater discharge. The above hypothesis is supported by several lines of evidence, including geological evidence on the frequency of historical floods (Ely et al. 1993; Knox 1993), decadal trends in freshwater discharge (Lins and Michaels 1994), and GCM scenarios (e.g., Miller and Russell 1992; Wolock and McCabe 1999).

In the United States, there is historical evidence suggesting that changes in climate enhance the frequency of extreme flood events. An analysis of a 5,000-year geological record for the southwestern U.S. (Ely et al. 1993) suggested that floods occurred more frequently during transitions from cool to warm climate conditions. Modest changes in climate were able to produce large changes in the magnitude of floods. Additional evidence in support of the above hypothesis came from a 7,000-year record of overbank floods for the upper Mississippi River tributaries (Knox 1993). Approximately 3,300 years ago, an abrupt shift in flood behavior occurred, with frequent floods of a magnitude that now recurs every 500 years or more. Analysis of the data collected by the U.S. Geological Survey indicated statistically significant increasing trends in monthly discharge averages during the past five decades across most of the conterminous U.S. (Lins and Michaels 1994). Similar results were obtained by a GCM-based study that examined the impacts of global warming on the annual discharge of the world's 33 largest rivers (Miller and Russell 1992). For a hypothetical $2 \mathrm{xCO}_{2}$ climate scenario, increases in discharge were indicated for 25 of the 33 studied rivers (Fig. 1). Model simulations suggested that the average annual discharge of the Mississippi River would increase $20 \%$ if the concentration of atmospheric $\mathrm{CO}_{2}$ doubles. Other studies have shown that runoff estimates for the Mississippi River Basin differed greatly between the Canadian model and the Hadley model (Wolock and McCabe 1999). The average annual runoff of the Mississippi River Basin, for example, was projected to decrease $30 \%$ for the Canadian model, but increase $40 \%$ for the Hadley model by the year 2099. Thus, the effects of global climate change on hydrological cycle are less certain, particularly on regional scales.

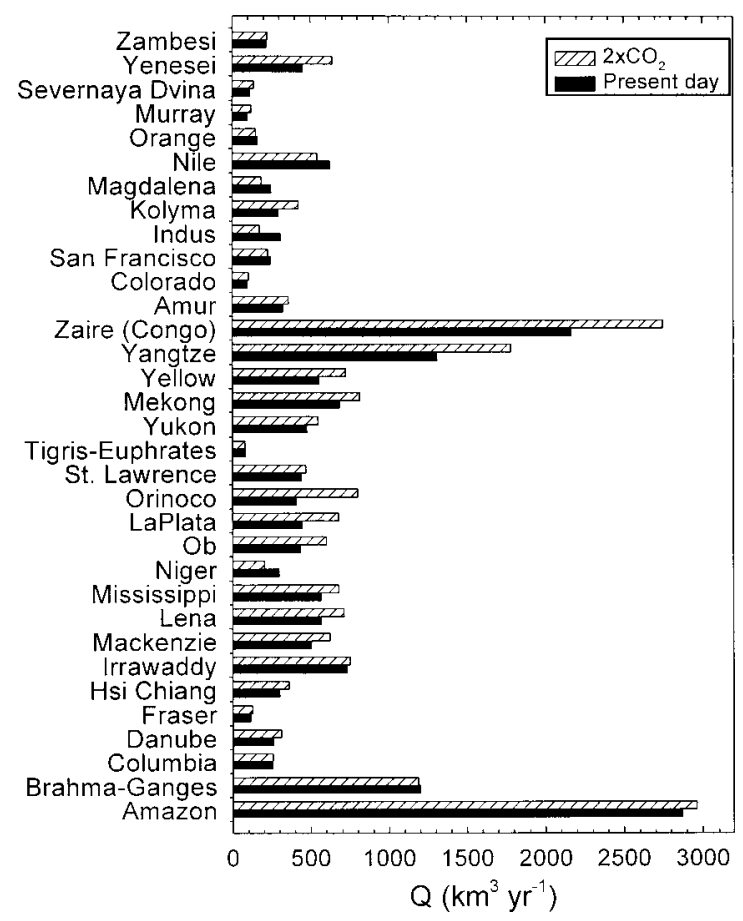

Fig. 1. Present day averages and projected $2 \mathrm{xCO}_{2}$ discharges (Q) for 33 of the world's major rivers (adapted from Miller and Russell 1992).

The purpose of this analysis is to investigate decadal and annual variability in nitrate flux of the lower Mississippi River between 1954 and 2000. Our objectives were to partition observed decadal trends and annual variability in nitrate flux among the key anthropogenic and climatic factors, i.e., nitrate concentration and discharge, and to test the hypothesis that climate change, via its influence on riverine nutrient fluxes, would have important implications for coastal marine eutrophication and hypoxia.

\section{Methods \\ THe MississipPI RIVER BASIN}

In terms of the size of the watershed, freshwater discharge, and sediment load, the Mississippi River ranks the third, sixth, and seventh in the world, respectively (Milliman and Meade 1983). The length of the Mississippi River mainstem is 3,700 $\mathrm{km}$. The Mississippi River Basin covers an area of $3.27 \times 10^{6} \mathrm{~km}^{2}$ or about $41 \%$ of the conterminous U.S. (Milliman and Meade 1983). It extends from the southern Canadian border on the north to the Gulf of Mexico on the south, and from the Appalachian Mountains on the east to the Rocky Mountains on the west.

The Mississippi River Basin is presently one of the most productive farming regions in the world, 
producing most of the corn, wheat, soybeans, and cattle in the U.S. During the last 150 years this region has been the site of unprecedented agricultural and urban developments. Beginning in the 1870 s, the central part of the Mississippi River Basin was subjected to extensive agricultural drainage (Zucker and Brown 1998). The hydrology of the Mississippi River has also been greatly altered by the construction of dams and reservoirs that started in the early 1900s (Meade 1995). The portion of land under cultivation and the population in the basin have increased to about $60 \%$ and 70 million, respectively (Goolsby et al. 1999). The use of nitrogen fertilizer in the U.S. began in the mid 1930s and has increased to about $12 \times 10^{9} \mathrm{~kg} \mathrm{yr}^{-1}$ by 1995 (Turner and Rabalais 1991; Turner et al. 1999). Those agricultural and urban developments have dramatically increased the inputs of nutrients into the tributaries and the mainstem of the Mississippi River. Total nitrogen yield for the Mississippi River Basin is presently between 2.5-fold to 7.5fold higher than that of a hypothetical pristine North Atlantic drainage basin (Howarth et al. 1996; Howarth 1998).

\section{DATA}

The daily-averaged discharge values for the lower Mississippi River at Tarbert Landing, Mississippi (August 1954-May 2000) were obtained from the U.S. Army Corps of Engineers. The monitoring station at Tarbert Landing is $478 \mathrm{~km}$ upstream from the birdfoot delta, and $13 \mathrm{~km}$ downstream from the inlet channel to the Old River control structure, where one-third of the Mississippi River is diverted to join the Red River to form the Atchafalaya River. The discharge at Tarbert Landing accounts for about $70 \%$ of the total Mississippi River and Atchafalaya River discharges. Daily-averaged discharges are inferred from data-adaptive models of discharge versus water level, whose accuracy is normally higher than $90 \%$ (Bratkovich et al. 1994). Monthly discharge averages, used in the nitrate flux calculations, were computed from the dailyaveraged discharge values. In this analysis, we used the monthly records (August 1954-May 2000) of nitrate concentration at St. Francisville, Louisiana, approximately $430 \mathrm{~km}$ upstream from the Mississippi River delta. Data sources and analytical methods used to determine nitrate concentrations are discussed in Turner and Rabalais (1991) and Goolsby et al. (1999).

\section{Partitioning of Nitrate Flux Among the Key Anthropogenic and Climatic Factors}

In order to evaluate the relative contribution of anthropogenic and climatic factors to Mississippi River nitrate flux, we compared historical changes
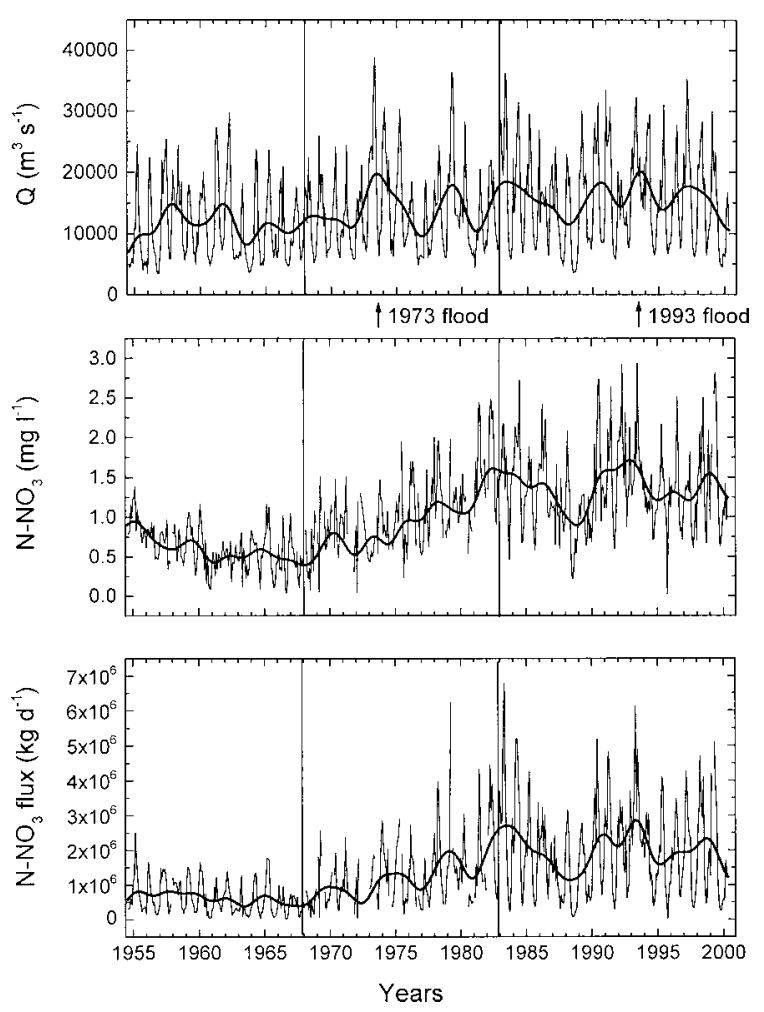

Fig. 2. Monthly averages (August 1954-May 2000) of the lower Mississippi River discharge (Q), nitrate concentration (N$\left.\mathrm{NO}_{3}\right)$, and nitrate flux $\left(\mathrm{N}_{-} \mathrm{NO}_{3}\right.$ flux $)$. Smoothed curves are estimated third order polynomial fits on 12-month weighted averages. Vertical lines denote the 1954-1967, 1968-1982, and 1983-2000 periods. Arrows indicate the 1973 and 1993 floods.

in nitrate concentration and discharge to the averages of the base period 1954-1967. The 19541967 period was chosen as a reference because it was the earliest period for which continuous nitrate concentration data were available and because it is characterized by a remarkably stable nitrate flux (Fig. 2). We assumed in this analysis that nitrate concentration is influenced predominantly by anthropogenic factors, i.e., loading from agricultural, industrial, and municipal sources (Howarth et al. 1996; Caraco and Cole 1999; Goolsby et al. 1999), while discharge is controlled predominantly by climatic factors, i.e., rainfall and temperature over the continental U.S.

Nitrate flux $\left(\mathrm{F}_{\mathrm{t}}, \mathrm{kg} \mathrm{s}^{-1}\right)$, may be expressed as a product of nitrate concentration $\left(\mathrm{N}_{\mathrm{t}}, \mathrm{kg} \mathrm{m}^{-3}\right)$ and discharge $\left(Q_{t}, \mathrm{~m}^{3} \mathrm{~s}^{-1}\right)$ :

$$
\mathrm{F}_{\mathrm{t}}=\mathrm{N}_{\mathrm{t}} \mathrm{Q}_{\mathrm{t}}
$$

where $t$ is time (yr). Average annual $\mathrm{N}_{\mathrm{t}}$ and $\mathrm{Q}_{\mathrm{t}}$ values reflect historical changes and may be decomposed as 
TABLE 1. Number of observations (n), averages $(\overline{\mathrm{x}})$, standard deviations (SD), and coefficients of variation (CV) of the Mississippi River discharge $(\mathrm{Q})$, nitrate concentration $\left(\mathrm{N}-\mathrm{NO}_{3}\right)$, and nitrate flux $\left(\mathrm{N}_{-} \mathrm{NO}_{3}\right.$ flux $)$ for the periods 1954-1967, 19681982, and 1983-2000. The differences in $\mathrm{Q}, \mathrm{N}-\mathrm{NO}_{3}$, and $\mathrm{N}-\mathrm{NO}_{3}$ flux between the three periods are highly significant $(\mathrm{p} \leq$ 0.001 ), based on one-way Analysis of Variance (ANOVA) and Duncan's Multiple Range Tests.

\begin{tabular}{lccc}
\hline \multicolumn{1}{c}{ Period } & $\mathrm{Q}\left(\mathrm{m}^{3} \mathrm{~s}^{-1}\right)$ & ${\mathrm{N}-\mathrm{NO}_{3}\left(\mathrm{mg} \mathrm{l}^{-1}\right)}$ & ${\mathrm{N}-\mathrm{NO}_{3} \text { flux }\left(\mathrm{kg} \mathrm{d}^{-1}\right)}$ \\
\hline $1954-1967$ & & & \\
$\mathrm{n}$ & 161 & 160 & 160 \\
$\overline{\mathrm{x}}$ & 11,381 & 0.61 & $0.63 \times 10^{6}$ \\
$\mathrm{SD}$ & 6,359 & 0.28 & $0.49 \times 10^{6}$ \\
$\mathrm{CV}$ & 0.56 & 0.45 & 0.77 \\
$1968-1982$ & & & \\
$\mathrm{n}$ & 180 & 153 & 153 \\
$\overline{\mathrm{x}}$ & 13,849 & 1.05 & $1.34 \times 10^{6}$ \\
$\mathrm{SD}$ & 7,104 & 0.49 & $0.99 \times 10^{6}$ \\
$\mathrm{CV}$ & 0.51 & 0.47 & 0.74 \\
$1983-2000$ & & & \\
$\mathrm{n}$ & 209 & 208 & 208 \\
$\overline{\mathrm{x}}$ & 15,874 & 1.37 & $2.01 \times 10^{6}$ \\
$\mathrm{SD}$ & 7,908 & 0.55 & $1.36 \times 10^{6}$ \\
$\mathrm{CV}$ & 0.49 & 0.4 & 0.67 \\
\hline
\end{tabular}

$$
\begin{aligned}
& \mathrm{N}_{\mathrm{t}}=\mathrm{N}_{\mathrm{B}}\left(1+\mathrm{f}_{\mathrm{Nt}}\right) \\
& \mathrm{Q}_{\mathrm{t}}=\mathrm{Q}_{\mathrm{B}}\left(1+\mathrm{f}_{\mathrm{Qt}}\right)
\end{aligned}
$$

where $\mathrm{N}_{\mathrm{B}}$ and $\mathrm{Q}_{\mathrm{B}}$ are the average nitrate concentration and the average discharge of the base period 1954-1967, and $\mathrm{f}_{\mathrm{Nt}}$ and $\mathrm{f}_{\mathrm{Ot}}$ are scaling factors, respectively. From Eqs. 1-3 it follows:

$$
\begin{aligned}
& \mathrm{V}_{\mathrm{Nt}}=\left[\mathrm{f}_{\mathrm{Nt}} /\left(\mathrm{f}_{\mathrm{Nt}}+\mathrm{f}_{\mathrm{Qt}}\right)\right] \times 100 \\
& \mathrm{~V}_{\mathrm{Qt}}=\left[\mathrm{f}_{\mathrm{Qt}} /\left(\mathrm{f}_{\mathrm{Nt}}+\mathrm{f}_{\mathrm{Qt}}\right)\right] \times 100
\end{aligned}
$$

where $\mathrm{V}_{\mathrm{Nt}}$ and $\mathrm{V}_{\mathrm{Qt}}$ are relative proportions (\%) of nitrate flux variability that can be explained by observed deviations in the nitrate concentration and discharge, respectively, relative to the base period 1954-1967.

\section{Results \\ LONG-TERM TRENDS}

The estimated polynomial trends in the time series of the lower Mississippi River discharge (Q), nitrate concentration $\left(\mathrm{N}-\mathrm{NO}_{3}\right)$, and nitrate flux $\left(\mathrm{N}-\mathrm{NO}_{3}\right.$ flux $)$ are shown in Fig. 2. Based on the annual flux averages and the overall variability in the data, it is possible to distinguish between three different periods. The 1954-1967 period is characterized by stable flux averages and generally low variability in flux. The 1968-1982 period is characterized by a strong upward trend in flux and also a gradual increase in flux variability. The 19832000 period is characterized by an apparent new flux equilibrium that is associated with the largest overall variability in the data. Between 1954-1967

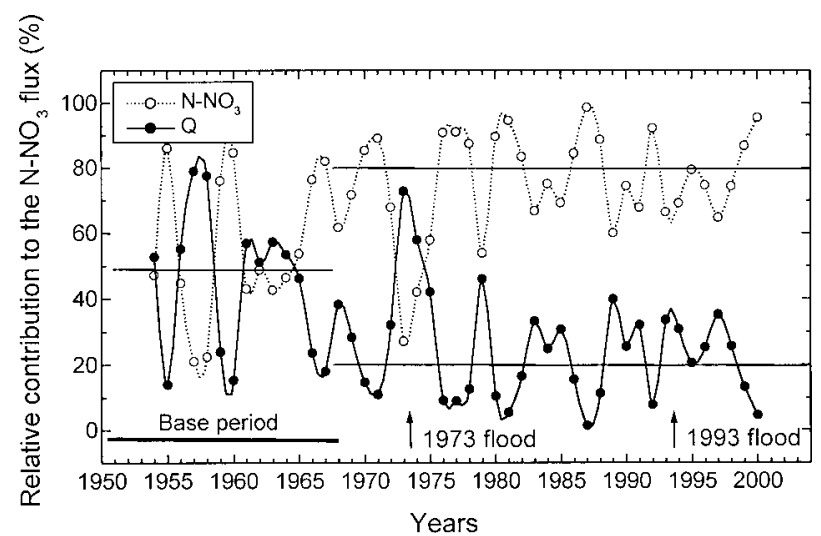

Fig. 3. Partitioning of observed trends in the $\mathrm{N}_{-} \mathrm{NO}_{3}$ flux of the lower Mississippi River into anthropogenic ( $\mathrm{N}^{-\mathrm{NO}_{3}}$ concentration) and climatic (discharge, Q) components. Symbols indicate relative contributions $(\%)$ of the two flux components, based on deviations from averages of the base period 19541967. Arrows indicate the 1973 and 1993 floods. Refer to the Methods section for additional explanation.

and 1983-2000, the average nitrate flux of the lower Mississippi River increased from $0.63 \times 10^{6}$ to $2.01 \times 10^{6} \mathrm{~kg} \mathrm{~d}^{-1}$, which is a 3.3 -fold increase (Table 1). During the same time period, the average nitrate concentration increased 2.3-fold (from 0.61 to $1.37 \mathrm{mg} \mathrm{N}-\mathrm{NO}_{3} \mathrm{l}^{-1}$ ), while the average discharge increased $40 \%$ (from 11,381 to $15,874 \mathrm{~m}^{3} \mathrm{~s}^{-1}$ ). All of these endpoint increases are statistically significant $(\mathrm{p} \leq 0.01$; Table 1$)$.

Partitioning of the observed trend in nitrate flux among the two flux components, nitrate concentration and discharge, reveals that about $80 \%$ of the observed historical increase in flux could be explained by the increase in nitrate concentration (Fig. 3). Deviations in discharge accounted for about $50 \%$ of the variability in flux during the 1954-1967 base period. This ratio subsequently decreased to about $20 \%$, in response to the upward trend in nitrate concentration. The influence of discharge on nitrate flux is clearly manifested at the extreme high end of the discharge spectrum. During the flood of 1973, for example, the deviations in discharge, with respect to the 1954-1967 period, accounted for about $70 \%$ of the observed variability in flux (Fig. 3). The average annual discharge during the flood of $1973\left(20,400 \mathrm{~m}^{3} \mathrm{~s}^{-1}\right)$ was comparable to that of the flood of 1993 $\left(21,800 \mathrm{~m}^{3} \mathrm{~s}^{-1}\right)$, but because of a compensatory influence of increased nitrate concentrations, the increase in discharge during 1993 accounted for a substantially lower fraction $(\sim 35 \%)$ of the variability in flux when compared to a similar event that occurred twenty years earlier (Fig. 3). 

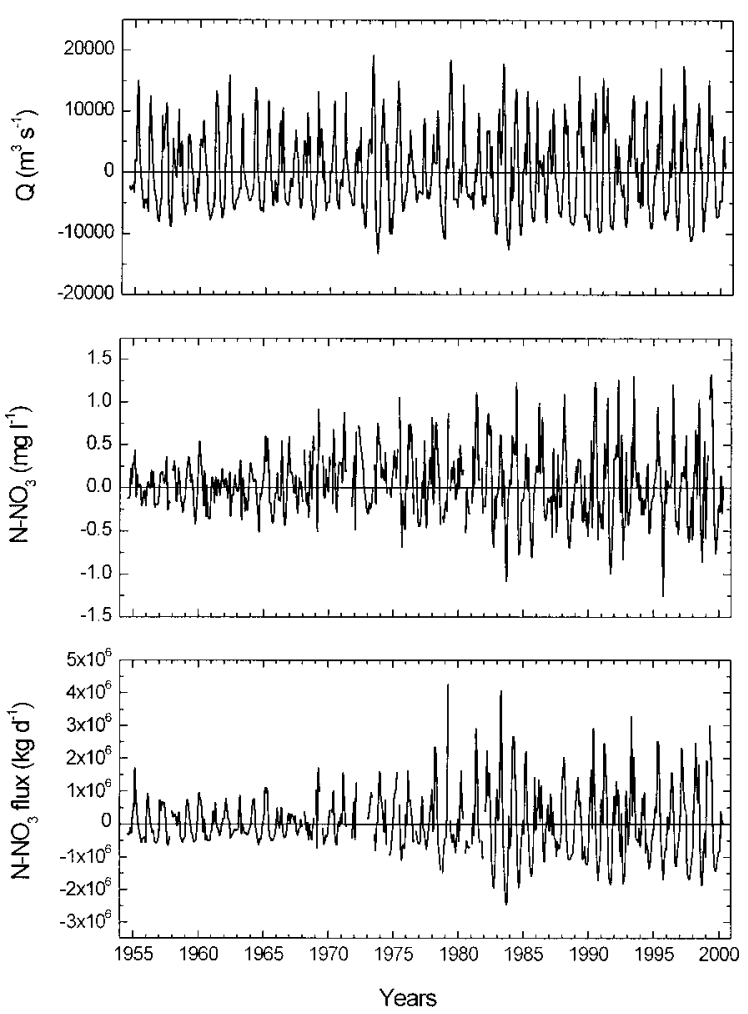

Fig. 4. Residual components of discharge $(Q)$, nitrate concentration $\left(\mathrm{N}-\mathrm{NO}_{3}\right)$ and nitrate flux $\left(\mathrm{N}^{-\mathrm{NO}_{3}}\right.$ flux) of the lower Mississippi River for 1954-2000. Residuals were obtained by subtracting the estimated polynomial trends from the time series in Fig. 2.

\section{RESIDUAL VARIABILITY}

Residual components of discharge, nitrate concentration, and nitrate flux were obtained by subtracting estimated polynomial trends from the time series (Fig. 4). A matrix of Pearson product-moment correlations was then generated to examine covariability among residual components of discharge, nitrate concentration, and nitrate flux.

The variability envelopes for nitrate concentration and flux showed a tendency to expand moderately over time (Fig. 4). Standard deviations for nitrate concentrations and flux increased 2-fold and 2.8-fold, respectively, between 1954-1967 and 1983-2000 (Table 1). The variability in discharge also increased 24\% between 1954-1967 and 19681982. The coefficients of variation (CV) for discharge were consistently higher than those for nitrate concentration (Table 1). Since CV provides a measure of relative variability, i.e., variability that is not affected by the average and is useful for comparison of different time series, it appears that the residual component of nitrate flux is predominantly controlled by variations in discharge. This hypothesis is further supported by the analysis of
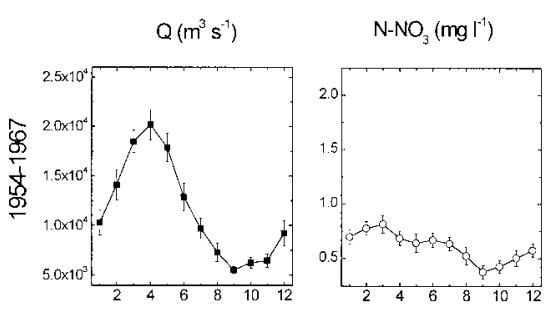

$\mathrm{N}-\mathrm{NO}_{3}$ flux $\left(\mathrm{kg} \mathrm{d}^{-1}\right)$
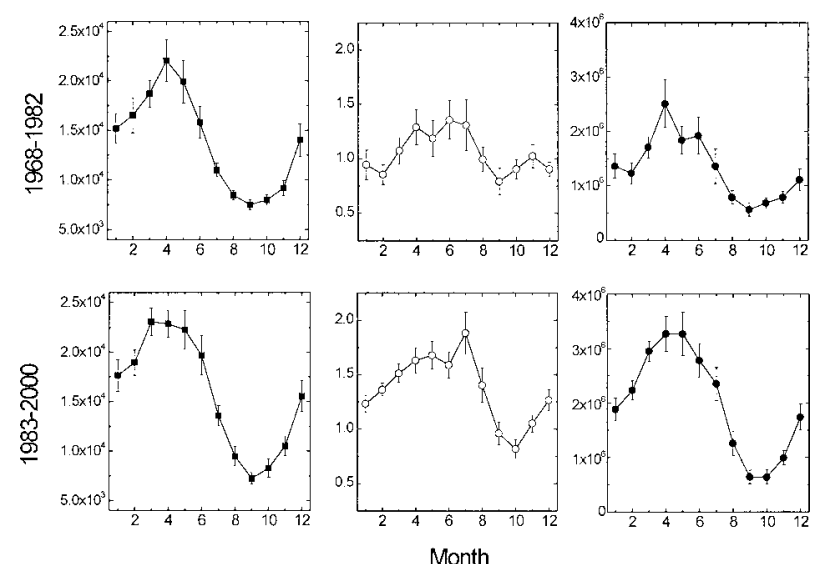

Fig. 5. Seasonal patterns in discharge $(\mathrm{Q})$, nitrate concentration $\left(\mathrm{N}^{-\mathrm{NO}_{3}}\right)$, and nitrate flux $\left(\mathrm{N}^{-\mathrm{NO}_{3}}\right.$ flux) of the lower Mississippi River during 1954-1967, 1968-1982, and 1983-2000. Vertical bars represent \pm 1 SE.

a matrix of Pearson product-moment correlations for residual components of discharge, nitrate concentration, and nitrate flux. The correlation of discharge and flux $\left(r^{2}=0.66 ; p \leq 0.001\right)$ is higher than the correlation of nitrate concentration and flux $\left(\mathrm{r}^{2}=0.52 ; \mathrm{p} \leq 0.001\right)$. The residuals of discharge and nitrate concentration are also highly correlated $\left(\mathrm{r}^{2}=0.11, \mathrm{p} \leq 0.001\right)$.

\section{SEAsonal Aspects}

The monthly discharge averages at Tarbert Landing for 1954-1967, 1968-1982, and 19832000 show a sinusoidal seasonal pattern (Fig. 5). This same sinusoidal pattern is also an attribute of longer records (Bratkovich et al. 1994). The maximum discharge typically occurs in April and decreases afterwards until a seasonal minimum in September. Two important historical changes in the seasonal discharge distribution are noticeable when the 1954-1967 and 1983-2000 data subsets are compared (Fig. 5). There is a significant $(\mathrm{p} \leq$ 0.01 ) increasing trend in the average monthly discharge during the March-May period. This trend has effectively prolonged the duration of the spring discharge maximum. There is also a significant $(p \leq 0.01)$ trend towards higher discharges during the August-December period. This latter trend has, in turn, reduced the duration of the late summer and early fall discharge minimum (Fig. 5). 


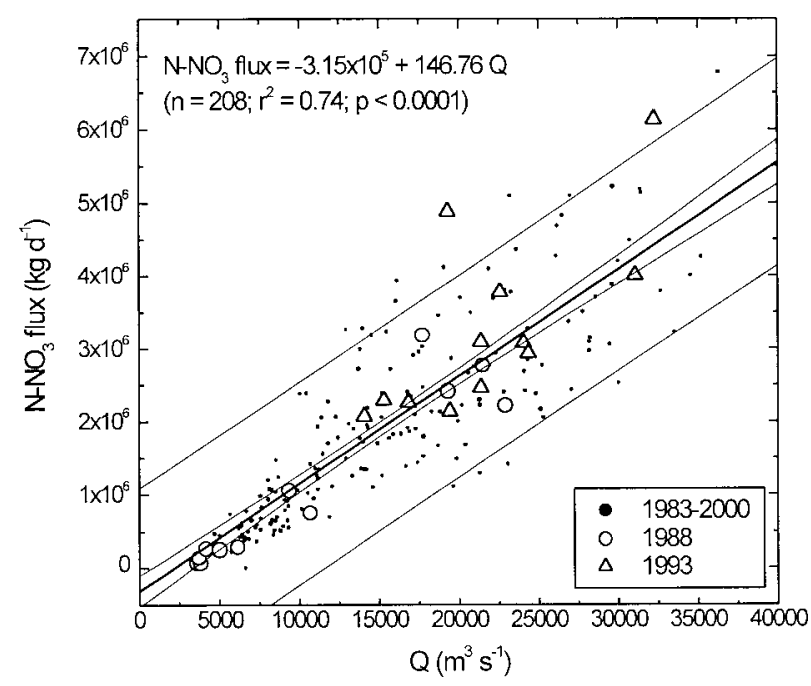

Fig. 6. Regression of nitrate flux $\left(\mathrm{N}-\mathrm{NO}_{3}\right.$ flux $)$ on discharge (Q) for the period 1983-2000. The values for the drought of 1988 and the flood of 1993 are shown in different symbols. The two pairs of lines parallel to the regression line denote the $95 \%$ confidence limits and the $95 \%$ prediction limits.

Both of those changes have contributed to a significant $40 \%$ increase in the average discharge between 1954-1967 and 1983-2000 (Table 1).

The seasonal pattern in the Mississippi River nitrate flux generally resembles the dynamics of the freshwater discharge. The timing and magnitude of the annual flux maximum during 1968-1982 and 1983-2000 has clearly been influenced by changes in the seasonal pattern in nitrate concentration (Fig. 5). The July maximum in nitrate concentration that has emerged during the last 30-40 years most likely is related to increased nitrogen inputs from fertilizers (Turner and Rabalais 1991).

\section{Causal Relationships}

Relationship between discharge and nitrate flux for the 1983-2000 data subset is depicted in Fig. 6. A linearity in flux-discharge relationships was also observed in the 1954-1967 and 1968-1982 data subsets. The regression slopes for 1954-1967 $\left(\mathrm{a}=62.35 ; \mathrm{r}^{2}=0.66 ; \mathrm{p} \leq 0.01\right)$ and $1968-1982(\mathrm{a}$ $\left.=96.12 ; \mathrm{r}^{2}=0.48 ; \mathrm{p} \leq 0.01\right)$ were markedly lower in comparison with the slope for the 1983-2000 (a $=146.76 ; \mathrm{r}^{2}=0.74 ; \mathrm{p} \leq 0.01$; Fig. 6). These differences correspond to historically lower nitrate concentrations during 1954-1967 and 1968-1982 (Fig. 2). Sensitivity of the Mississippi River nitrate flux to altered discharge was estimated by computing the percent increase in flux that corresponds to a $1 \%$ increase in the average discharge. For the 1983-2000 data subset, the average flux sensitivity was $1.16 \%$.

To examine the flux-discharge relationship
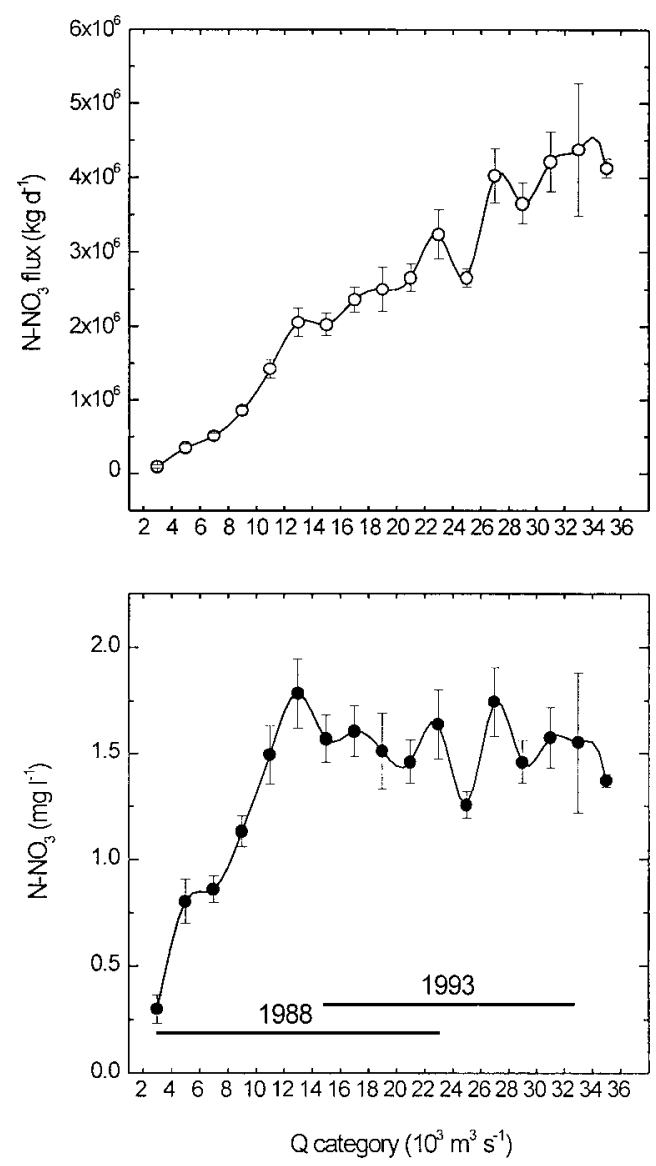

Fig. 7. Relationships between discharge (Q), nitrate concentration $\left(\mathrm{N}-\mathrm{NO}_{3}\right)$, and nitrate flux $\left(\mathrm{N}^{-\mathrm{NO}_{3}}\right.$ flux $)$ of the lower Mississippi River during 1983-2000. Discharge was subdivided into 18 categories, each corresponding to a range in discharge of $2,000 \mathrm{~m}^{3} \mathrm{~s}^{-1}$. Symbols denote average nitrate concentrations and fluxes corresponding to the respective discharge categories. Vertical bars represent \pm 1 standard error. The two horizontal lines in the lower panel show the range of monthly discharge values during the drought of 1988 and the flood of 1993.

more closely, the data on nitrate concentration and flux were subdivided into 18 categories, each corresponding to a range in discharge of $2,000 \mathrm{~m}^{3} \mathrm{~s}^{-1}$ (Fig. 7). This analysis demonstrated that there is a tendency towards nonlinearity at the low end of the discharge spectrum, up to about $13,000 \mathrm{~m}^{3} \mathrm{~s}^{-1}$. Nitrate concentration is also highly correlated with discharge up to about $13,000 \mathrm{~m}^{3} \mathrm{~s}^{-1}(\mathrm{a}=1.35 \times$ $10^{-4} ; r^{2}=0.35 ; p \leq 0.001 ;$ Fig. 7$)$. At higher discharges, nitrate concentration appears to be independent of discharge. This peculiar relationship between discharge and nitrate concentration is affecting nitrate flux, primarily by amplifying differences in flux between the flood years and drought years. The average nitrate concentration during the flood of 1993 (1.72 $\mathrm{mg} \mathrm{N}^{-1}$; Table 2), for example, was significantly higher $(p \leq 0.01)$ when 
TABLE 2. Numbers of observations $(\mathrm{n})$, averages $(\overline{\mathrm{x}})$, standard deviations (SD), and coefficients of variation (CV) of the Mississippi River discharge $(\mathrm{Q})$, nitrate concentration $\left(\mathrm{N}-\mathrm{NO}_{3}\right)$, and nitrate flux $\left(\mathrm{N}_{-} \mathrm{NO}_{3}\right.$ flux) for the drought of 1988 and the flood of 1993. The differences in $\mathrm{Q}, \mathrm{N}-\mathrm{NO}_{3}$, and $\mathrm{N}-\mathrm{NO}_{3}$ flux between the two periods are highly significant $(\mathrm{p} \leq 0.001)$, based on a two-sample $t$-test.

\begin{tabular}{|c|c|c|c|}
\hline Period & $\mathrm{Q}\left(\mathrm{m}^{3} \mathrm{~s}^{-1}\right)$ & $\begin{array}{c}\mathrm{N}^{\mathrm{NO}_{3}} \\
\left(\mathrm{mg} \mathrm{l}^{-1}\right)\end{array}$ & $\mathrm{N}-\mathrm{NO}_{3}$ flux $\left(\mathrm{kg} \mathrm{d}^{-1}\right)$ \\
\hline \multicolumn{4}{|l|}{1988} \\
\hline $\mathrm{n}$ & 12 & 12 & 12 \\
\hline$\overline{\mathrm{x}}$ & 10,647 & 0.92 & $1.12 \times 10^{6}$ \\
\hline SD & 7,582 & 0.57 & $1.18 \times 10^{6}$ \\
\hline CV & 0.71 & 0.62 & 1.05 \\
\hline \multicolumn{4}{|l|}{1993} \\
\hline $\mathrm{n}$ & 12 & 12 & 12 \\
\hline$\overline{\mathrm{x}}$ & 21,837 & 1.72 & $3.26 \times 10^{6}$ \\
\hline SD & 5,618 & 0.46 & $1.25 \times 10^{6}$ \\
\hline $\mathrm{CV}$ & 0.25 & 0.27 & 0.38 \\
\hline Difference (1993-1988) & 2.05 & 1.87 & 2.91 \\
\hline
\end{tabular}

compared with the 1983-2000 average (1.37 mg N $1^{-1}$; Table 1$)$. The average monthly discharges during 1993 were always above 13,000 $\mathrm{m}^{3} \mathrm{~s}^{-1}$ (Fig. 7). The opposite was the case during the drought of 1988, when monthly discharge averages were below 13,000 $\mathrm{m}^{3} \mathrm{~s}^{-1}$ during the May-December period (Fig. 7). The average annual nitrate concentration in 1988 decreased to $0.92 \mathrm{mg} \mathrm{N}^{-1}$ (Table 2 ), the lowest observed value during the entire 1983-2000 period. While the average Mississippi River discharge increased two-fold between 1988 and 1993, the average nitrate flux increased threefold (Table 2).

\section{Doubled $\mathrm{CO}_{2}$ Scenario}

Based on simulations of a general circulation model, Miller and Russell (1992) predicted that the average annual discharge of the Mississippi River would increase $20 \%$ if the concentration of atmospheric $\mathrm{CO}_{2}$ doubles (Fig. 1). While there are other runoff estimates for the Mississippi River Basin (Wolock and McCabe 1999), this scenario is in agreement with the observed historical increases in discharge across the conterminous U.S. (Lins and Michaels 1994). Assuming a 20\% increase in discharge with respect to the 1983-2000 period (Table 1 ), the average $2 \mathrm{xCO}_{2}$ discharge of the lower Mississippi River would be around 19,000 $\mathrm{m}^{3} \mathrm{~s}^{-1}$. This value is somewhat lower than the annual average for the flood of $1993\left(21,837 \mathrm{~m}^{3} \mathrm{~s}^{-1}\right.$; Table $2)$. We expect that the variability in discharge would increase coincidentally with the increase in the average discharge. This assumption is supported by the fact that a $40 \%$ increase in the average discharge between 1954-1967 and 1983-2000 was associated with a $24 \%$ increase in the variability in discharge (Table 1).

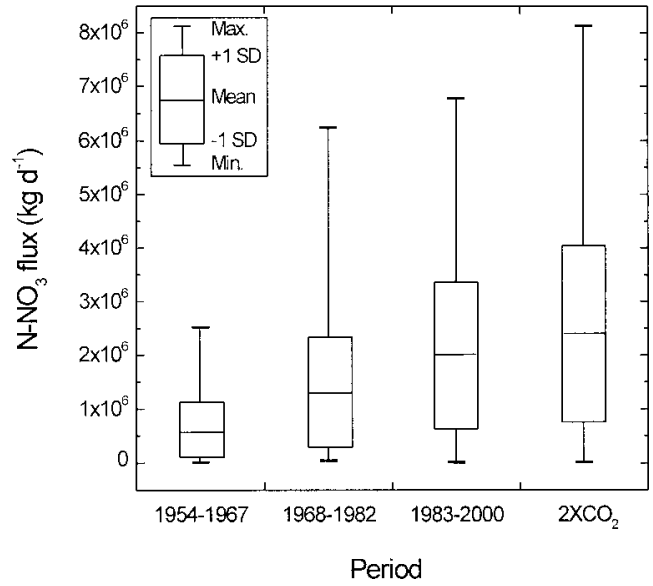

Fig. 8. Box-plots showing the Mississippi River nitrate flux (N-NO ${ }_{3}$ flux) statistics for 1954-1967, 1968-1982, 1983-2000, and a hypothetical $2 \mathrm{xCO}_{2}$ scenario based on a $20 \%$ increase in discharge (Miller and Russell 1992).

It is impossible at this time to reliably predict future trends in nitrate concentration of the lower Mississippi River. If nutrient control programs for the Mississippi River Basin are implemented (Brezonik et al. 1999; Goolsby et al. 1999; Rabalais et al. 2002), nitrate concentration may decrease, although nitrate concentration may increase in response to an increase in discharge. For the purpose of this analysis, we assume that nitrate concentration will not change with respect to the period 1983-2000. By substituting a hypothetical $2 \mathrm{xCO}_{2}$ discharge of $19,000 \mathrm{~m}^{3} \mathrm{~s}^{-1}$ into the equation in Fig. 6, we obtained an estimate of $2.47 \times 10^{6} \mathrm{~kg}$ $\mathrm{d}^{-1}$ for the average annual $2 \mathrm{xCO}_{2}$ nitrate flux (Fig. 8 ). If a $20 \%$ increase in flux variability, relative to 1983-2000 $\left(\mathrm{SD}=1.36 \times 10^{6} \mathrm{~kg} \mathrm{~d}^{-1}\right.$; Table 1$)$ is also assumed, then the maximum nitrate flux may exceed $8 \times 10^{6} \mathrm{~kg} \mathrm{~d}^{-1}$ (Fig. 8). This latter value would be higher than any monthly nitrate flux value on record for the entire 1954-2000 period (Fig. 2).

\section{Discussion \\ Climatic Influences on Riverine Nitrate Flux}

The average nitrate flux of the lower Mississippi River increased 3.3-fold between 1954-1967 and 1983-2000 (Fig. 2; Table 1). During the same time period, the average nitrate concentration increased 2.3-fold, while the average discharge increased $40 \%$. Partitioning of the observed trend in nitrate flux among the two flux components, nitrate concentration and discharge, revealed that about $80 \%$ of the observed increase in flux could be explained by the increase in nitrate concentration (Fig. 3). This indicates that historical increase in the anthropogenic nutrient inputs has had a far 
greater impact on the lower Mississippi River nitrate flux then a change in climate. The influence of climatic factors on nitrate flux has been significant and may further increase as a result of global climate change. This argument is supported by two lines of evidence. The residual component of nitrate flux, obtained by removing a trend from the time series, is controlled primarily by the variability in discharge, i.e., climatic factors. There is also a highly significant relationship between discharge and nitrate concentration at the low end of the discharge spectrum, up to about $13,000 \mathrm{~m}^{3} \mathrm{~s}^{-1}$ (Fig. 7). Because the difference in nitrate flux between a flood year and a drought year is significantly larger than the difference in discharge (Table 2), the lower Mississippi River nitrate flux is potentially sensitive to future changes in the frequency of extreme climatic events. Our estimated sensitivity of nitrate flux to altered Mississippi River discharge was $1.16 \%$, which was somewhat higher in comparison with a previously reported value of $1.10 \%$ (Alexander et al. 1996). Flux sensitivity values above $1 \%$ are indicative generally of rivers where discharge, either from agricultural, urban, or forested lands, is the predominant source of nitrate (Alexander et al. 1996). Because of the amplified influence of discharge on nitrate flux in the Mississippi River, future nutrient control efforts (i.e., Brezonik et al. 1999; Goolsby et al. 1999; Rabalais et al. 2002) may be more challenging.

There are several ways in which changes in precipitation and discharge may influence riverine nitrate flux. The higher precipitation would leach more nitrate from soils into tributaries and the mainstem of the Mississippi River (Goolsby et al. 1999). Unless riverine nitrate concentrations are reduced, the higher discharge would possibly lead to an increased nitrate flux. Higher discharge would also decrease the water residence times in canals, lakes, and small streams in the upper parts of the watershed. This would substantially reduce nitrogen losses due to denitrification (Howarth et al. 1996; Alexander et al. 2000), and ultimately result in a higher nitrate concentration in the mainstem of the Mississippi River. Even if we assume that there would be no change in the nitrate concentrations of the lower Mississippi River with respect to the 1983-2000 period, a hypothetical $20 \%$ increase in discharge would probably result in a greater nitrate flux (Fig. 8).

\section{IMPLICATION FOR COASTAL EUTROPHICATION AND HYPOXIA}

The combined discharges of the Mississippi and Atchafalaya Rivers account for $96 \%$ and $98 \%$ of the total freshwater and nitrogen fluxes, respectively, into the northern Gulf of Mexico (Dunn 1996;
Dinnel and Wiseman 1986). Nitrate concentrations in the Lower Mississippi River are typically an order of magnitude higher that those in the Gulf's coastal waters (Justić et al. 1995a). Nitrogen is often considered to be the limiting nutrient for the growth of estuarine and coastal phytoplankton (e.g., D'Elia et al. 1986), and the proportions of nutrients in the Gulf's coastal waters also indicate a high incidence $(\sim 30 \%)$ of stoichiometric nitrogen limitation (Justić et al. 1995a,b). The variability in the Mississippi River nitrate flux has profound implications for nutrient enhanced coastal productivity (Lohrenz et al. 1997, 1999) and the eutrophication process in general.

Changes in the areal extent of hypoxic $(<2 \mathrm{mg}$ $\mathrm{O}_{2} \mathrm{l}^{-1}$ ) bottom waters in the northern Gulf of Mexico between flood and drought years provide perhaps the best example of the riverine influence on coastal eutrophication. The northern Gulf of Mexico is presently the site of the largest $(>20,000$ $\mathrm{km}^{2}$ ) and the most severe coastal hypoxic zone in the western Atlantic Ocean (Rabalais et al. 1999; Rabalais and Turner 2001). Hypoxia normally occurs from April through September in waters below the pycnocline and extends to water depths of $60 \mathrm{~m}$. During the drought of 1988, however, bottom oxygen concentrations were significantly higher than average, and formation of a continuous hypoxic zone along the coast did not occur in midsummer. The opposite occurred during the flood of 1993, when the areal extent of summertime hypoxia doubled with respect to the average hydrologic year (Rabalais et al. 1998, 1999). Hypoxia in the coastal bottom waters develops as a synergistic product of high surface primary productivity, which leads to a higher carbon flux to the sediments and high water column stability. The 1993 hypoxia was associated with both an increased stability of the water column and nutrient-enhanced primary productivity, as indicated by the greatly increased nutrient concentrations and phytoplankton biomass in the coastal waters influenced by the Mississippi River (Dortch 1994; Rabalais et al. 1998).

Strong riverine influence implies that the ecosystem of the northern Gulf of Mexico would be highly sensitive to climate-induced changes in riverine freshwater and nutrient fluxes. In a series of modeling studies Justić et al. (1996, 1997, 2002) examined the impacts of climate variability on the Gulf's hypoxic zone. Model simulations suggested that increased freshwater discharge (20\%, Miller and Russell 1992) and increased temperatures (2$4^{\circ} \mathrm{C}$, Giorgi et al. 1994) would significantly affect the stability of the water column. Vertical density gradients between the upper $(0-10 \mathrm{~m})$ and the lower (10-20 m) water column would increase, ex- 
ceeding values observed during the peak of the flood of 1993 (Justić et al. 1996). Increased riverine nitrogen flux during the late spring would enhance the net productivity of the upper water column. Following a 20\% increase in the annual Mississippi River discharge, the annual net productivity value at a station within the core of the hypoxic zone would increase $53 \%$, from $122 \mathrm{gC} \mathrm{m}^{-2} \mathrm{yr}^{-1}$ (the 1985-1992 average) to $187 \mathrm{gC} \mathrm{m}^{-2} \mathrm{yr}^{-1}$. This later value is $21 \%$ higher than the annual net productivity value for the flood of 1993 (Justić et al. 1997). Model results also suggested that the summertime subpycnoclinal $(10-20 \mathrm{~m})$ oxygen content would decrease $30-60 \%$, relative to the $1985-$ 1992 average, leading perhaps to an expanded hypoxic zone.

\section{IMPLICATIONS FOR FISHERIES FOOD WEBS}

Among all the manifestations of eutrophication, hypoxia perhaps has the most profound impact on coastal food webs (Pearson and Rosenberg 1992; Diaz and Rosenberg 1995, 2001). Negative effects of hypoxia have been reported from a variety of coastal and estuarine areas, ranging from mass mortalities of benthic organisms (Stachowitsch 1984; Rosenberg 1985; Boesch and Rabalais 1991; Rabalais et al. 2001) to species extinctions (Officer et al. 1984; Benović et al. 1987).

In the northern Gulf of Mexico, commercial and recreational fisheries depend on life cycles of species located within shallow continental shelf waters that overlap with the hypoxic zone. Fishery-independent surveys revealed reduction or absence of shrimp and other mobile species in hypoxic waters (Craig et al. 2001). White shrimp avoid water with dissolved oxygen concentrations below $1.5 \mathrm{mg} \mathrm{l}^{-1}$ and brown shrimp are even more sensitive, avoiding water with oxygen concentrations below $2.0 \mathrm{mg}$ $1^{-1}$ (Renaud 1986b). This behavior leads to an observed blocking effect on juvenile shrimp emigrating from inshore nurseries to offshore feeding and spawning grounds. A negative correlation between shrimp catch and the presence of hypoxia corroborates interference with shrimp movement (Zimmerman and Nance 2001). In spite of the fact that Gulf's fishery yields have remained high over the last 40 years (Chesney and Baltz 2001), the catch per unit effort of brown shrimp has declined $20 \%$ from mid 1980s to the late 1990s (Zimmerman and Nance 2001). This change has occurred coincidentally with an increase in the areal extent of hypoxia (Rabalais and Turner 2001).

Studies from the northern Gulf of Mexico have shown that demersal species abundance and diversity are drastically reduced where hypoxic conditions exist (Pavella et al. 1983; Renaud 1986a). Mass mortalities are known to occur in the benthic infauna when bottom oxygen concentration decreases below $0.5 \mathrm{~g} \mathrm{O}_{2} \mathrm{~m}^{-3}$ (Gaston 1985; Rabalais et al. 1999, 2001). The overall structure of the benthic community in the hypoxic zone is shifted towards a polychaete-dominated fauna of smaller individuals and lower standing stock. Presently, there is a significant recovery of the benthic community in the fall, and further recruitment in the subsequent spring. Any future increase in areal extent and severity of hypoxia would likely reduce food resources for recolonizing demersal groups and altering the productivity base that leads to fishery stocks.

\section{ACKNOWLEDGMENTS}

This research was funded in part by the National Oceanic and Atmospheric Administration Coastal Ocean Program grants for hypoxia studies (N-GOMEX 2000) and the U.S. Department of Energy's National Institute for Global Environmental Change.

\section{Literature Gited}

Alexander, R. B., P. S. Murdoch, And R. A. Smith. 1996. Streamflow-induced variations in nitrate flux in tributaries to the Atlantic Coastal Zone. Biogeochemistry 33:149-177.

Alexander, R. B., P. S. Murdoch, R. A. Smith, and G. E. SCHWARZ. 2000. Effect of stream channel size on the delivery of nitrogen to the Gulf of Mexico. Nature 403:758-761.

Andersson, L. AND L. RYDBERG. 1988. Trends in nutrient and oxygen conditions within the Kattegat: Effects on local nutrient supply. Estuarine, Coastal and Shelf Science 26:559-579.

Benović, T., D. Justić, And A. Bender. 1987. Enigmatic changes in the hydromedusan fauna of the northern Adriatic Sea. Nature 326:597-600.

Boesch, D. AND N. N. Rabalais. 1991. Effects of hypoxia on continental shelf benthos: Comparison between the New York Bight and the northern Gulf of Mexico, p. 27-34. In R. V. Tyson and T. H. Pearson (eds.), Modern and Ancient Continental Shelf Anoxia. Special Publication No. 58. Geological Society, London, U.K.

Bratkovich, A., S. P. Dinnel, And D. A. Goolsby. 1994. Variability and prediction of freshwater and nitrate fluxes for the Louisiana-Texas shelf: Mississippi and Atchafalaya River source functions. Estuaries 17:766-778.

Brezonik, P. L., V. J. Bierman, JR., R. Alexander, J. Anderson, J. Barko, M. Dortch, L. Hatch, G. L. Hitchcock, D. Keeney, D. Mulla, V. Smith, C. Walker, T. Whitledge, and W. J. WisEMAN, JR. 1999. Effects of reducing nutrient loads to surface waters within the Mississippi River Basin and the Gulf of Mexico. Topic 4 Report for the Integrated Assessment of Hypoxia in the Gulf of Mexico. NOAA Coastal Ocean Program Decision Analysis Series No. 18. National Oceanic and Atmospheric Administration Coastal Ocean Program, Silver Spring, Maryland.

Caraco, N. F. And J. J. Cole. 1999. Human impact on nitrate export: An analysis using major world rivers. Ambio 28:167170.

Chesney, E. J. And D. M. Baltz. 2001. The effects of hypoxia on the northern Gulf of Mexico coastal ecosystem: A fisheries perspective, p. 321-354. In N. N. Rabalais and R. E. Turner (eds.), Coastal Hypoxia: Consequences for Living Resources and Ecosystems. Coastal and Estuarine Studies 58, American Geophysical Union, Washington, D.C.

CoOper, S. R. AND G. S. BRUsh. 1991. Long-term history of Chesapeake Bay anoxia. Science 254:992-996.

Craig, J. K., L. B. Crowder, C. D. Gray, C. J. McDaniel, T. A. 
HenwoOd, AND J. G. Hanifen. 2001. Ecological effects of hypoxia on fish, sea turtles, and marine mammals in the northwestern Gulf of Mexico, p. 269-291. In N. N. Rabalais and R. E. Turner (eds.), Coastal Hypoxia: Consequences for Living Resources and Ecosystems. Coastal and Estuarine Studies 58, American Geophysical Union, Washington, D.C.

D'Elia, C. J., J. G. SANDERS, AND W. R. Boynton. 1986. Nutrient enrichment studies in a coastal plain estuary: Phytoplankton growth in large-scale, continuous cultures. Canadian Journal of Fisheries and Aquatic Sciences 43:397-406.

Diaz, R. J. AND R. Rosenberg. 1995. Marine benthic hypoxia: A review of its ecological effects and behavioral responses of benthic macrofauna. Oceanography and Marine Biology Annual Review 33:245-303.

DiAz, R. J. AND R. RosenberG. 2001. Overview of anthropogenically-induced hypoxic effects on marine benthic fauna, p. 129-145. In N. N. Rabalais and R. E. Turner (eds.), Coastal Hypoxia: Consequences for Living Resources and Ecosystems. Coastal and Estuarine Studies 58, American Geophysical Union, Washington, D.C.

Dinnel, S. AND W. J. Wiseman, JR. 1986. Freshwater on the Louisiana shelf. Continental Shelf Research 6:765-784.

DORTCH, Q. 1994. Changes in phytoplankton number and species composition, p. 46-49. In M. J. Dowgiallo (ed.), Coastal Oceanographic Effects of Summer 1993 Mississippi River Flooding. National Oceanic and Atmospheric Administration Coastal Ocean Office/National Weather Service, Silver Spring, Maryland.

DorTch, Q. AND T. E. Whitledge. 1992. Does nitrogen or silicon limit phytoplankton production in the Mississippi River plume and nearby regions? Continental Shelf Research 12:12931309.

DunN, D. D. 1996. Trends in nutrient inflows to the Gulf of Mexico from streams draining the conterminous United States 1972-1993. Water-Resources Investigations Report 964113. U.S. Geological Survey, Austin, Texas.

ELY, L. L., Y. ENZEL, V. R. BAKER, AND D. R. CAYAN. 1993. A 5000year record of extreme floods and climate change in the southwestern United States. Nature 262:410-412.

Gaston, G. R. 1985. Effects of hypoxia on macrobenthos of the inner shelf off Cameron, Louisiana. Estuarine, Coastal and Shelf Science 20:603-613.

Giorgi, F., C. Shields-Brodeur, ANd T. Bates. 1994. Regional climate change scenarios produced with a nested regional climate model. Journal of Climate 7:375-399.

Goolsby, D. A., W. A. Battaglin, G. B. Lawrence, R. S. Artz, B. T. Aulenbach, R. P. Hooper, D. R. Keeney, and G. J. StensLAND. 1999. Flux and sources of nutrients in the MississippiAtchafalava River Basin. Topic 3 Report for the Integrated Assessment of Hypoxia in the Gulf of Mexico. NOAA Coastal Ocean Program Decision Analysis Series No. 17. National Oceanic and Atmospheric Administration Coastal Ocean Program, Silver Spring, Maryland.

Hickel, W., P. Mangelsdorf, And J. Berg. 1993. The human impact in the German Bight: Eutrophication during three decades (1962-1991). Helgolander Meeresunters 47:243-263.

HOWARTH, R. W. 1998. An assessment of human influences on fluxes of nitrogen from the terrestrial landscape to the estuaries and continental shelves of the North Atlantic Ocean. Nutrient Cycling in Agroecosystems 52:213-223.

Howarth, R. W., G. Billen, D. Swaney, A. Townsend, N. JawOrski, K. Lajtha, J. A. Downing, R. E. Elmgren, N. Caraco, T. Jordan, F. BerENDSE, J. FrenEy, V. KudEyarov, P. Murdoch, AND Z.-L. ZHU. 1996. Regional nitrogen budgets and riverine $\mathrm{N}$ and $\mathrm{P}$ fluxes for the drainages to the North Atlantic Ocean: Natural and human influences. Biogeochemistry 35:75-139.

Intergovernmental PANEL ON Climate Change (IPCC). 2001. Climate Change 2001: The Scientific Basis, Contribution of
Working Group I to the Third Assessment Report. Cambridge University Press, Cambridge, U.K.

Jones, P. D., M. New, D. E. Parker, S. Martin, and I. G. Rigor. 1999. Surface air temperature and its changes over the past 150 years. Reviews of Geophysics 37:173-199.

Justić, D., T. Legović, And L. RotTini-SANDRini. 1987. Trend in the oxygen content 1911-1984 and occurrence of benthic mortality in the northern Adriatic Sea. Estuarine, Coastal and Shelf Science 25:435-445.

Justić, D., N. N. Rabalais, and R. E. Turner. 1995a. Stoichiometric nutrient balance and origin of coastal eutrophication. Marine Pollution Bulletin 30:41-46.

Justić, D., N. N. Rabalais, AND R. E. Turner. 1996. Effects of climate change on hypoxia in coastal waters: A doubled $\mathrm{CO}_{2}$ scenario for the northern Gulf of Mexico. Limnology and Oceanography 41:992-1003.

Justić, D., N. N. Rabalais, AND R. E. Turner. 1997. Impacts of climate change on net productivity of coastal waters: Implications for carbon budget and hypoxia. Climate Research 8: 225-237.

Justić, D., N. N. Rabalais, And R. E. Turner. 2002. Modeling the impacts of decadal changes in riverine nutrient fluxes on coastal eutrophication near the Mississippi River Delta. Ecological Modelling 152:33-46.

Justić, D., N. N. Rabalais, R. E. Turner, and Q. Dortch. 1995b. Changes in nutrient structure of river-dominated coastal waters: Stoichiometric nutrient balance and its consequences. Estuarine, Coastal and Shelf Science 40:339-356.

Knox, J. C. 1993. Large increases in flood magnitude in response to modest changes in climate. Nature 361:430-432.

LiNS, H. F. AND P. J. MichaELS. 1994. Increasing U.S. streamflow linked to greenhouse forcing. Eos, Transactions, American Geophysical Union 75:281.

Lohrenz, S. E., G. L. Fahnenstiel, D. G. Redalje, G. A. Lang, X. Chen, AND M. J. DagG. 1997. Variations in primary production of northern Gulf of Mexico continental shelf waters linked to nutrient inputs from the Mississippi River. Marine Ecology Progress Series 55:435-454.

Lohrenz, S. E., G. L. Fahnenstiel, D. G. Redalje, G. A. Lang, M. J. DAgG, T. E. Whitledge, And Q. Dortch. 1999. The interplay of nutrients, irradiance and mixing as factors regulating primary production in coastal waters impacted by the Mississippi River plume. Continental Shelf Research 19:11131141.

MEADE, R. H. (ED.). 1995. Contaminants in the Mississippi River, 1987-1992. U.S. Geological Survey Circular 1133. U.S. Department of the Interior, U.S. Geological Survey, Denver, Colorado.

Miller, J. R. AND G. L. Russell. 1992. The impact of global warming on river discharge. Journal of Geophysical Research 97: $2757-2764$.

Milliman, J. D. and R. H. Meade. 1983. Worldwide delivery of river sediment to the ocean. Journal of Geology 91:1-21.

Officer, C. C., R. B. Biggs, J. L. Taft, L. E. Cronin, M. Tyler, AND W. R. Boynton. 1984. Chesapeake Bay anoxia: Origin, development and significance. Science 223:22-27.

Pavella, J. S., J. L. Ross, AND M. E. ChitTEndEN, JR. 1983. Sharp reduction in abundance of fishes and benthic macroinvertebrates in the Gulf of Mexico off Texas associated with hypoxia. Northeast Gulf Science 6:167-173.

PEARson, T. AND R. RosenberG. 1992. Energy flow through the SE Kattegat: A comparative examination of the eutrophication of a coastal marine ecosystem. Netherlands Journal of Sea Research 28:317-334.

Peierls, B. L., N. Caraco, M. Pace, and J. Cole. 1991. Human influence on river nitrogen. Nature 350:386-387.

Rabalais, N. N., D. E. Harper, and R. E. Turner. 2001. Responses of nekton and demersal and benthic fauna to decreasing oxygen concentrations, p. 115-128. In N. N. Rabalais 
and R. E. Turner (eds.), Coastal Hypoxia: Consequences for Living Resources and Ecosystems. Coastal and Estuarine Studies 58, American Geophysical Union, Washington, D.C.

Rabalais, N. N. AND R. E. TuRnER. 2001. Hypoxia in the northern Gulf of Mexico: Description, causes and change, p. 1-36. In N. N. Rabalais, and R. E. Turner (eds.), Coastal Hypoxia: Consequences for Living Resources and Ecosystems. Coastal and Estuarine Studies 58, American Geophysical Union, Washington, D.C.

Rabalais, N. N., R. E. Turner, D. Justić, Q. Dortch, And W. J. Wiseman, JR. 1999. Characterization of Hypoxia: Topic 1 Report for the Integrated Assessment of Hypoxia in the Gulf of Mexico. NOAA Coastal Ocean Program Decision Analysis Series No. 15. NOAA Coastal Ocean Program, Silver Spring, Maryland.

Rabalais, N. N., R. E. Turner, D. Justić, Q. Dortch, W. J. WiseMAN, JR., AND B. K. SEN GUPTA. 1996. Nutrient changes in the Mississippi River and system responses on the adjacent continental shelf. Estuaries 19:386-407.

Rabalais, N. N., R. E. Turner, and D. Scavia. 2002. Beyond science into policy: Gulf of Mexico hypoxia and the Mississippi River. BioScience 52:129-142.

Rabalais, N. N., R. E. Turner, W. J. Wiseman, JR., and Q. DORTCH. 1998. Consequences of the 1993 Mississippi River flood in the Gulf of Mexico. Regulated Rivers: Research and Management 14:161-177.

RenAud, M. L. 1986a. Hypoxia in Louisiana coastal waters during 1983: Implications for fisheries. Fishery Bulletin 84:19-26.

RENAud, M. L. 1986b. Detecting and avoiding oxygen deficient sea water by brown shrimp, Penaeus aztecus (Ives) and white shrimp Penaeus setiferus (Linnaeus). Journal of Experimental Marine Biology and Ecology 98:283-292.

ROSENBERG, R. 1985. Eutrophication-The future marine coastal nuisance? Marine Pollution Bulletin 16:227-231.

SMAYDA, T. J. 1990. Novel and nuisance phytoplankton blooms in the sea: Evidence for global epidemic, p. 29-40. In E. Graneli, B. Sundstrom, R. Edler, and D. M. Anderson (eds.), Toxic Marine Phytoplankton. Elsevier Science, New York.
Stachowitsch, M. 1984. Mass mortality in the Gulf of Trieste: The course of community destruction. PSZNI: Marine Ecology 5:243-264.

Turner, R. E. AND N. N. Rabalais. 1991. Changes in the Mississippi River water quality this century-Implications for coastal food webs. BioScience 41:140-147.

Turner, R. E. AND N. N. Rabalais. 1994. Evidence for coastal eutrophication near the Mississippi River delta. Nature 368: 619-621.

Turner, R. E., N. N. Rabalais, And D. Justić. 1999. Long-term watershed and water quality changes in the Mississippi River system, p. 37-50. In W. J. Wiseman, Jr., N. N. Rabalais, M. Dagg, and T. E. Whitledge (eds.), Nutrient Enhanced Coastal Productivity in the Northern Gulf of Mexico. NOAA Coastal Ocean Program, Decision Analysis Series No. 14. NOAA Coastal Ocean Program, Silver Spring, Maryland.

Vitousek, P. M., J. D. Aber, R. W. Howarth, G. E. Likens, P. A. Matson, D. W. Schindler, W. H. Schlesinger, and D. G Tilman. 1997. Human alterations of the global nitrogen cycle: Sources and consequences. Ecological Applications 7:737-750.

Wolock, D. M. AND G. J. McCABE. 1999. Estimates of runoff using water-balance and atmospheric general circulation models. Journal of the American Water Resources Association 35: 1341-1350.

Zimmerman, R. J. AND J. NANCE. 2001. Effects of hypoxia on the shrimp fishery of Louisiana and Texas, p. 293-310. In N. N. Rabalais and R. E. Turner (eds.), Coastal Hypoxia: Consequences for Living Resources and Ecosystems. Coastal and Estuarine Studies 58, American Geophysical Union, Washington, D.C.

Zucker, L. A. AND L. C. Brown. 1998. Agricultural drainage: Water quality impacts and subsurface drainage studies in the Midwest. Ohio State University Extension Bulletin 871. Ohio State University, Columbus, Ohio.

Received for consideration, May 21, 2001

Revised, June 12, 2002

Accepted for publication, June 27, 2002 